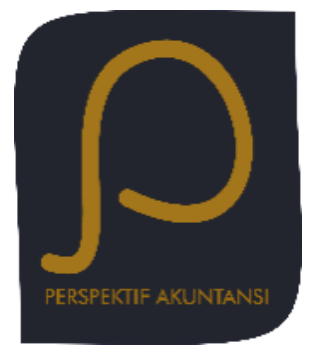

Perspektif Akuntansi

Volume 2 Nomor 2 (Juni 2019), hal. 145-167

ISSN: 2623-0194 (Print), 2623-0186 (Online) Copyright@ The Authors(s). All Rights Reserved

Fakultas Ekonomika dan Bisnis,

Universitas Kristen Satya Wacana

DOI: https://doi.org/10.24246/persi.v1i2.p145-167

http://ejournal.uksw.edu/persi

\title{
Faktor Penentu Penggunaan Informasi dan Dampaknya terhadap Kinerja Perusahaan
}

\author{
Alexandra Adriani Widjaja ${ }^{1}$ \\ Fakultas Ekonomi dan Bisnis, UNIKA Soegijapranata
}

Received Abstract. Information technology is often referred as one of the 20 Maret 2019 factors that can improve company performance. Information technology itself has many aspects and capabilities, but its main Accepted function is to produce information for decision makers. So improving 26 Juni 2019 the performance of the company is actually supported by the level of utilization of information by the decision makers. This study aims to examine the effect of information use on the company's financial performance. This study also examined the influence of individual competencies and knowledge sharing on information use. Hypothesis are tested using Structural Equation Modeling (SEM). The results of this study indicate that information use has an effect on company performance. This study also found that information use is influenced by the opportunity for knowledge sharing, but is not influenced by individual competencies. This research also cannot empirically prove the indirect influence of knowledge sharing variables on company performance through information usage variables.

Keywords: Individual competence, knowledge sharing, information use, company performance

\begin{abstract}
Abstrak. Teknologi informasi sering disebut sebagai salah satu faktor yang dapat meningkatkan kinerja perusahaan. Teknologi informasi itu sendiri memiliki banyak aspek dan kapabilitas, akan tetapi fungsi utamanya adalah menghasilkan informasi bagi para pengambil keputusan. Maka peningkatan kinerja perusahan sebenarnya didukung oleh tingkat pemanfaatan informasi oleh para pengambil keputusan. Penelitian ini bertujuan menguji pengaruh penggunaan informasi terhadap kinerja keuangan
\end{abstract}

1 alexandra.adriani.w@gmail.com 
perusahaan. Penelitian ini juga menguji pengaruh kompetensi individu dan knowledge sharing terhadap penggunaan informasi. Pengujian dilakukan dengan menggunakan Structural Equation Modelling (SEM). Hasil penelitian ini menunjukkan penggunaan informasi berpengaruh terhadap kinerja perusahaan. Penelitian ini menemukan bahwa penggunaan informasi dipengaruhi oleh adanya kesempatan knowledge sharing, tetapi tidak dipengaruhi oleh kompetensi individu. Penelitian ini juga tidak dapat membuktikan secara empiris adanya pengaruh tidak langsung dari variabel knowledge sharing terhadap kinerja perusahaan melalui variabel penggunaan informasi.

Kata kunci: Kompetensi individu, knowledge sharing, penggunaan informasi, kinerja perusahaan

\section{Pendahuluan}

Saat ini bisnis telah mengalami transformasi digital. Teknologi digital melekat hampir pada seluruh proses bisnis dalam sebuah perusahaan (Turban, Volonino \& Woods, 2015). Digitalisasi ini menyebabkan perusahaan dapat mengambil keuntungan kompetitif dari inovasi. Banyak faktor yang dapat mempengaruhi inovasi apa saja yang dapat dilakukan oleh sebuah organisasi, di antaranya adalah data dan infomasi yang dimiliki perusahaan. Era digitalisasi telah membanjiri perusahaan dengan informasi, atau yang lebih dikenal dengan istilah big data. Volume informasi yang besar ini dapat menjadi keunggulan kompetitif bagi perusahaan bila dapat dimanfaatkan dengan baik.

Dalam sebuah proses bisnis, informasi merupakan salah satu komponen penting dalam pengambilan keputusan. Perkembangan teknologi pun dimanfaatkan untuk memastikan tersedianya informasi yang berkualitas. Perusahaan menerapkan sistem informasi terintegrasi untuk memastikan informasi yang dihasilkan sesuai dengan yang dibutuhkan. Sistem informasi itu pun memanfaatkan program-program terkomputerisasi yang memastikan ketersediaan informasi dari hulu ke hilir. Akan tetapi, keberhasilan implementasi suatu sistem informasi bukan hanya dilihat dari kemampuan sistem tersebut untuk menghasilkan informasi, melainkan bagaimana informasi tersebut dimanfaatkan dalam pengambilan keputusan. Sistem informasi dan teknologi informasi yang menyertainya hadir sebagai komponen pendukung proses bisnis inti di dalam perusahaan (Romney \& Steinbart, 2015). Teknologi informasi merupakan pendukung aktivitas primer perusahaan (Romney \& Steinbart, 2015). Penggunaan teknologi 
informasi seharusnya dapat mendukung pengambilan keputusan perusahaan bila informasi tersebut dapat dimanfaatkan dengan baik.

Teknologi memang menjadi salah satu faktor yang mendukung kinerja perusahaan. Bila teknologi diartikan secara luas, maka teknologi bisa mendukung kinerja perusahaan melalui banyak hal. Teknologi bisa digunakan untuk meningkatkan efektivitas dan efisiensi lantai produksi. Teknologi dapat menggantikan beberapa kegiatan klerikal yang tadinya dikerjakan oleh manusia. Tidak jarang kehadiran teknologi bahkan meniadakan beberapa prosedur manual sehingga proses bisnis menjadi lebih cepat. Teknologi juga secara nyata dapat memberikan informasi dengan frekuensi yang lebih sering dan waktu pengolahan yang lebih singkat.

Liu, Ke, Kee, dan Hua (2013) dalam penelitiannya mengakui teknologi informasi telah menjadi alat persaingan kompetitif antar perusahaan. Akan tetapi, kapabilitas teknologi informasi yang seperti apa yang dapat mempengaruhi kinerja perusahaan, masih perlu diteliti lebih lanjut. Teknologi informasi yang diterapkan dalam sebuah perusahaan terdiri dari berbagai macam unsur. Turban dan Volonino (2015) menyatakan bahwa penerapan teknologi informasi meliputi empat unsur, meliputi kesesuaian teknologi dengan proses bisnis dan tujuan perusahaan, desain aplikasi, manajemen basis data, serta perangkat keras yang digunakan. Hal ini menunjukkan kesuksesan pemanfaatan teknologi informasi untuk meningkatkan kinerja perusahaan dapat didukung oleh banyak faktor. Akan tetapi, belum banyak penelitian yang meneliti tentang faktor apa yang sebenarnya sangat mempengaruhi keberhasilan pemanfaatan sistem informasi dapat meningkatkan kinerja perusahaan.

Berdasarkan teori awal bahwa informasi adalah output yang dihasilkan dari sebuah sistem (Romney \& Steinbart, 2015), maka teknologi informasi dapat dipandang sebagai alat untuk memproses input untuk menghasilkan output. Peran infrastuktur dan arsitektur teknologi informasi jelas akan mempengaruhi output yang dihasilkan. Akan tetapi, hal ini juga menunjukkan bahwa yang sesungguhnya terkait dengan pengambilan keputusan adalah informasi yang dihasilkan oleh sistem tersebut. Oleh karenanya, dengan kata lain, tingkat pemanfaatan informasi oleh pengguna dapat mempengaruhi kinerja perusahaan. Bila tingkat pemanfaatan informasi oleh pengguna ternyata berpengaruh 
pada kinerja perusahaan, maka penting untuk memahami faktor-faktor apa yang dapat menunjang pemanfaatan informasi tersebut.

Di satu sisi, pemanfaatan informasi erat kaitannya dengan sumber daya manusia dalam perusahaan. Kemampuan sumber daya manusia untuk menggunakan informasi tersebut menjadi salah satu kunci keberhasilan sistem informasi dalam proses pengambilan keputusan. Sedangkan di sisi lain, kemampuan sumber daya manusia dalam hal ini tidak lagi mencakup kemampuan kognitif individu terkait dengan pekerjaannya, tetapi juga kemampuan teknis dalam menggunakan teknologi informasi. Kurangnya pengetahuan dan pengalaman dalam memanfaatkan teknologi informasi dapat mengakibatkan keengganan dalam menggunakan teknologi informasi. Keengganan ini pada akhirnya berujung pada kinerja keuangan yang kurang baik (Wahyudi, 2009). Penelitian Choi, Lee, dan Yoo (2010) juga menemukan bahwa dukungan teknologi informasi secara teknis kepada para pengguna teknologi informasi meningkatkan kemampuan mereka untuk menggunakan teknologi tersebut. Kemampuan individu untuk dapat memanfaatkan teknologi informasi dapat meningkatkan aplikasi pengetahuan di dalam proses kerja dan pada akhirnya meningkatkan kinerja perusahaan.

Meskipun kompetensi individu sangat berperan dalam pemanfaatan teknologi sistem informasi, faktor kerjasama di dalam anggota tim juga menjadi pertimbangan. Adanya kemungkinan untuk berbagi pengetahuan (knowledge sharing) di antara para individu juga berperan dalam pemanfaatan teknologi sistem informasi di dalam perusahaan tersebut. Darban, Kwak, Deng, Srite, dan Lee (2016) dalam penelitiannya menyatakan bahwa di dalam sebuah organisasi, seorang individu memerlukan informasi dari rekan atau teman satu timnya untuk dapat bertindak atau berperilaku seperti yang diharapkan. Penelitian Caya, Léger, Grebot, dan Brunelle (2014) juga menunjukkan bahwa adanya knowledge sharing di dalam perusahaan akan mendorong pemanfaatan informasi secara positif. Hal ini didukung oleh pergerakan teknologi informasi yang semakin terintegrasi. Data silo mulai ditinggalkan dan beralih ke manajemen basis data terintegrasi (Romney \& Steinbart, 2015). Dengan basis data yang terintegrasi maka informasi menjadi lebih accessible dan memfasilitasi knowledge sharing di dalam perusahaan.

Dari uraian di atas, penelitian ini menguji apakah kinerja keuangan perusahaan dipengaruhi oleh penggunaan informasi di dalam 
perusahaan tersebut. Penelitian ini juga menguji pengaruh kompetensi individu dan knowledge sharing terhadap penggunaan informasi itu sendiri. Penelitian ini juga menguji bagaimana pengaruh tidak langsung knowledge sharing terhadap kinerja keuangan perusahaan.

\section{Telaah Pustaka}

\section{Pengembangan Hipotesis}

Model kesuksesan sistem informasi menyatakan bahwa kepuasan individu dalam penggunaan informasi akan meningkatkan kinerja individu dan pada akhirnya akan meningkatkan kinerja organisasi (DeLone \& McLean, 2003; Emeka-Nwokeji, 2012; Saira, Zariyawati, \& Annuar, 2014). Penelitian-penelitian ini menunjukkan bahwa peran individu sebagai pengguna informasi sangat menentukan bagaimana informasi akan dimanfaatkan untuk mendukung pekerjaan mereka. Shah, Horne, dan Capella (2012) menyatakan bahwa data yang baik belum tentu menghasilkan keputusan yang baik pula. Tanpa kemampuan analitis yang baik, maka data yang baik sekalipun tidak akan bermanfaat bagi pengambilan keputusan. Penelitian tersebut menunjukkan bahwa kemampuan menganalisa data perlu dimiliki oleh setiap individu di dalam perusahaan, bukan hanya sekelompok orang di dalam perusahaan tersebut.

Penelitian Liu, Ke, Kee, dan Hua (2013) menyatakan teknologi informasi menjadi keunggulan kompetitif bila perusahaan tersebut mampu menyerap teknologi informasi tersebut. Bila perusahaan tidak memiliki kapabilitas untuk menyerap teknologi informasi, maka teknologi informasi tidak akan mampu memfasilitasi peningkatan kinerja perusahaan. Penelitian Rahayu dan Day (2015) meneliti tentang faktor yang mempengaruhi usaha kecil dan menengah (small-medium enterprise) dalam mengadopsi e-commerce. Dalam penelitiannya kemampuan dan pengalaman teknolgi informasi pemilik usaha menjadi salah satu faktor yang berpengaruh dalam keputusan menggunakan $e$ commerce. Penelitian lain tentang adopsi e-commerce juga dilakukan oleh Ghobakhloo, Arias-aranda, dan Benitez-amado (2011) juga menyatakan bahwa pengetahuan teknologi informasi dari pemilik informasi mempengaruhi keputusan pemilik untuk mengadopsi $e$ commerce. Berdasarkan uraian sebelumnya, hipotesis pertama dalam penelitian ini dirumuskan sebagai berikut: 
$\mathrm{H}_{1}$ : Kompetensi individu berpengaruh positif dan signifikan terhadap penggunaan informasi

Faktor kompetensi individu tentu bukan satu-satunya penentu keberhasilan kinerja perusahaan. Oliveira, Martins, dan Lisboa (2011) dalam studi literaturnya menyatakan bahwa kinerja perusahaan dipengaruhi oleh faktor teknologi, faktor organisasi, dan faktor lingkungan. Kerangka pikir ini sering juga dikenal sebagai Technology, Organization, and Environment (TOE) framework. Rahmawati (2012) juga menyatakan bahwa kondisi-kondisi yang memfasilitasi pemakaian sistem informasi mempengaruhi penggunaan sistem informasi. Kedua penelitian tersebut menunjukkan bahwa selain kemampuan individu, masih ada faktor-faktor lingkungan yang mempengaruhi penggunaan sistem informasi dalam organisasi. Proses berbagi (sharing) pengetahuan sangat penting bagi keberhasilan pemanfaatan teknologi informasi.

Untuk memanfaatkan teknologi informasi secara maksimal, seorang individu harus lebih dahulu mengeksplorasi dan mengenali teknologi tersebut sebelum akhirnya dapat memanfaatkan informasi yang dihasilkannya (Maruping \& Magni, 2012). Penelitian Kang et al. (2012) dalam Darban, Kwak, Deng, Srite, dan Lee (2016) menyatakan bahwa di dalam sebuah tim, seorang individu mengandalkan informasi dari rekan satu timnya untuk memahami sebuah informasi. Caya, et al. (2014) dalam penelitiannya mengemukakan bahwa manajemen pengetahuan di dalam sebuah tim atau sebuah organisasi memilih pengaruh positif terhadap kinerja pemrosesan informasi. Manajemen pengetahuan yang dimaksud dalam penelitian ini adalah adanya kesempatan untuk berbagi pengetahuan antara anggota tim serta mengintegrasikan pengetahuan yang dimiliki masing-masing anggota tim. Berdasarkan penelitianpenelitian tersebut, kerjasama di dalam tim dalam rangka knowledge sharing dapat mempengaruhi penggunaan informasi dalam organisasi.

Wang dan Noe (2010) memperkenalkan kerangka pikir tentang manajemen pengetahuan. Dalam artikelnya, mereka menyatakan bahwa knowledge sharing merupakan dasar dari manajemen pengetahuan. Beberapa penelitian lain telah membuktikan bahwa manajemen pengetahuan memiliki dampak terhadap kinerja organisasi atau perusahaan. Penelitian Vacaro, Parente, dan Veloso (2010) membuktikan bahwa manajemen pengetahuan berpengaruh positif 
pada inovasi dan kinerja perusahaan. Hal ini sejalan dengan hasil penelitian Wang dan Wang (2012) mengenai knowledge sharing, inovasi dan kinerja perusahaan. Hasil penelitian mereka menunjukkan knowledge sharing berpengaruh positif terhadap kinerja perusahaan. Penelitian mereka bahkan membuktikan bahwa knowledge sharing memiliki pengaruh langsung terhadap kinerja perusahaan itu sendiri. Penelitian-penelitian ini menunjukkan bahwa knowledge sharing mempengaruhi penggunaan informasi di dalam perusahaan dan juga dapat berpengaruh secara langsung terhadap kinerja perusahaan tersebut. Mills (2011) dalam penelitiannya tentang knowledge management menemukan bahwa organisasi yang memiliki fasilitas atau proses untuk berbagi pengetahuan secara internal memiliki kinerja yang lebih baik. Berdasarkan uraian ini, maka dirumuskan hipotesis sebagai berikut:

H2: Knowledge sharing berpengaruh positif dan signifikan terhadap penggunaan informasi

H3: Knowledge sharing secara tidak langsung berpengaruh positif dan signifikan terhadap kinerja perusahaan

Penelitian Liang, You, dan Liu (2010) memberikan bukti bahwa pemanfaatan teknologi informasi dapat meningkatkan kapabilitas organisasi dalam menyelenggarakan operasionalnya. Dengan demikian, teknologi informasi yang dimanfaatkan dengan optimal juga dapat meningkatkan kinerja perusahaan. Mithas, Tafti, Bardhan, dan Goh (2012) dalam penelitiannya membuktikan bahwa teknologi informasi memfasilitasi perusahaan untuk mencapai profitabilitas yang tinggi. Lebih jauh lagi penelitian mereka membuktikan bahwa teknologi informasi yang memfasilitasi peningkatan pendapatan lebih bermanfaat dibandingkan teknologi informasi yang menurunkan biaya. Pemanfaatan teknologi informasi berupa implementasi sistem informasi pada perusahaan kecil dan menengah juga menunjukkan hasil yang sama, yaitu peningkatan kinerja perusahaan (Kharuddin, Ashhari, \& Nassir, 2010). Penelitian Alzoubi (2011) juga menunjukkan bahwa teknologi informasi mendukung ketersediaan informasi akuntansi yang lebih baik. Beberapa penelitian justru membuktikan bahwa teknologi informasi berdampak positif secara langsung terhadap kinerja manajerial (Frestilia, 2013; Widiastuti, 2011). 
Sistem informasi dalam sebuah organisasi menjadi salah satu pendukung dari aktivitas primer perusahaan. Serangkaian prosedur, kegiatan klerikal maupun pengolahan informasi terkomputerisasi disusun dengan tujuan mengolah data menjadi informasi yang dapat digunakan untuk mengambil keputusan (Romney \& Steinbart, 2015; Siynabola, 2012; Soudani, 2012). Namun, tentu saja informasi tersebut tidak akan berpengaruh pada kinerja perusahaan bila informasi tersebut tidak digunakan oleh para pengambil keputusan. Citroen (2011) menyatakan bahwa ada tidaknya informasi, sangat berperan dalam mengurangi ketidakpastian dalam pengambilan keputusan. Semakin banyak informasi relevan yang tersedia, maka para pengambil keputusan dapat mempertimbangkan berbagai macam alternatif dengan dasar yang rasional dan proses pengambilan keputusan menjadi lebih terkontrol. Pengambilan keputusan berdasarkan data dapat meningkatkan produktivitas perusahaan dan kinerja operasional perusahaan secara keseluruhan (Brynjolfsson, Hitt, \& Kim, 2011; Brynjolfsson \& Mcelheran, 2016; Chae, Yang, Olson, \& Sheu, 2014). Oleh karena itu hipotesis keempat dalam penelitian ini dirumuskan sebagai berikut:

$\mathrm{H}_{4}$ : Penggunaan informasi berpengaruh positif dan signifikan terhadap kinerja perusahaan

\section{Metodologi Penelitian}

\section{Partisipan}

Penelitian eksperimen ini melibatkan mahasiswa program studi Akuntansi sebagai partisipan. Sebanyak 234 mahasiswa yang mengikuti mata kuliah Sistem Informasi Manajemen terlibat dalam eksperimen ini. Terdapat 53 partisipan tidak lolos uji manipulasi dan 11 kuesioner tidak valid sehingga total partisipan dalam penelitian ini adalah 170 orang. Mereka terbagi menjadi kelompok-kelompok beranggotakan empat sampai lima orang. Masing-masing kelompok menjalankan sebuah perusahaan virtual dengan menggunakan MonsoonSIM ERP Games. MonsoonSIM ERP games dipakai sebagai simulator operasional bisnis. Dalam simulasi ini, masing-masing tim akan menjalankan sebuah perusahaan virtual yang bergerak di bidang manufaktur dan jasa. Tim 
bersaing satu dengan lainnya dalam pasar virtual dengan kondisi awal perusahaan yang sama persis dalam hal modal dan tenaga kerja.

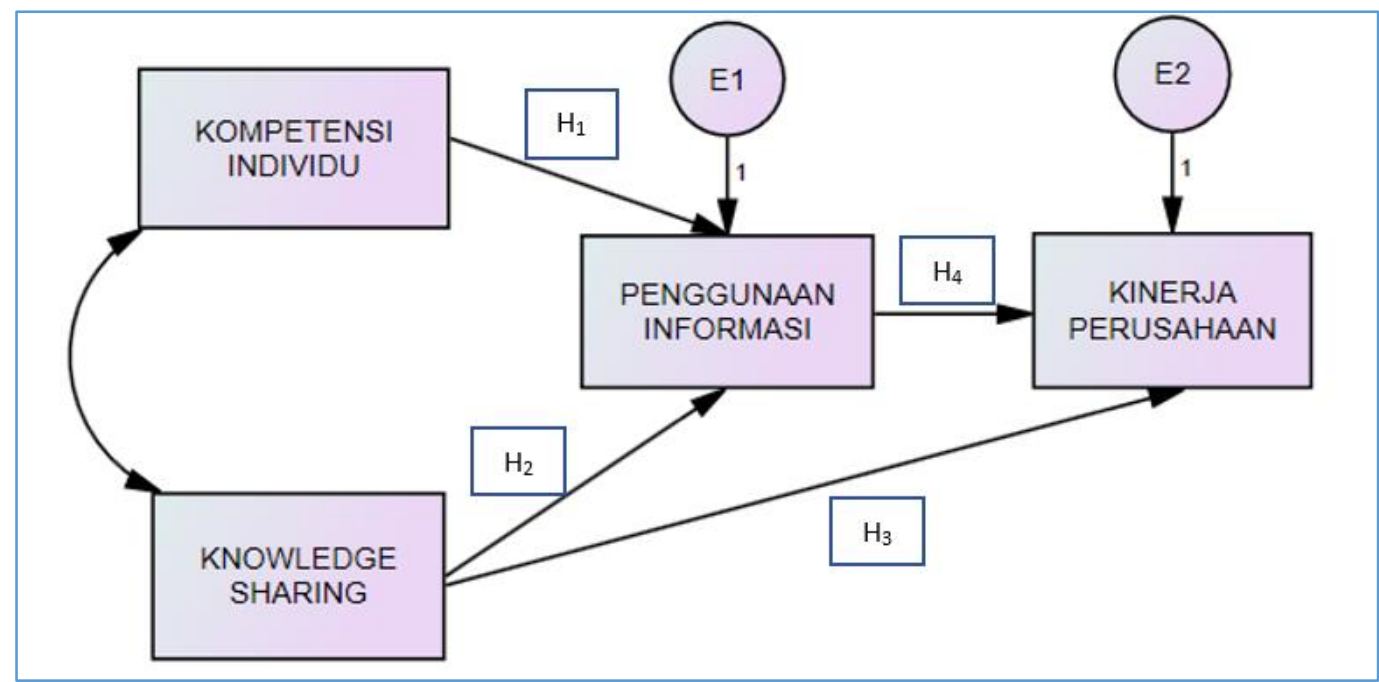

Gambar 1. Model Penelitian

\section{Pengukuran Variabel}

\section{Kompetensi Individu}

Kompetensi individu dalam penelitian ini adalah kemampuan individu dalam mengoperasikan komputer secara umum, dan kemampuan penguasaan software komputer. Partisipan diminta untuk mengukur sendiri keahlian komputer mereka dengan menggunakan kuesioner berisi 27 pertanyaan. Keahlian komputer mereka diperlukan agar dapat memanfaatkan sistem informasi dalam simulasi tersebut.

\section{Knowledge Sharing}

Dalam penelitian ini, knowledge sharing diukur dengan menggunakan durasi waktu diskusi yang berbeda. Satu kelompok partisipan diberi waktu 1,5 menit untuk berdiskusi sedangkan kelompok yang lain diberi waktu 10 menit untuk berdiskusi. Lamanya waktu diskusi diasumsikan sama dengan kesempatan untuk berbagi pengetahuan di dalam tim. Setiap individu menjalankan fungsi yang spesifik di dalam tim. Setiap fungsi ini memberikan informasi yang berbeda dan tentunya memberikan pengetahuan yang berbeda tentang berbagai hal mengenai proses bisnis yang sedang disimulasikan saat itu. Pengetahuan yang 
didiskusikan untuk pengukuran variabel ini mencakup teknis operasional sistem informasi, pembagian tugas dan strategi perusahaan.

\section{Penggunaan Informasi}

Dalam penelitian ini penggunaan informasi diukur dengan banyaknya jenis informasi yang digunakan selama menjalankan simulasi perusahaan virtual. Pada akhir setiap putaran, masing-masing individu diberikan sebuah daftar jenis-jenis informasi yang disediakan oleh sistem informasi selama simulasi berlangsung. Setiap individu lalu diminta untuk memilih jenis informasi apa saja yang ia gunakan selama menjalankan simulasi, khususnya yang ia gunakan untuk dapat menjalankan fungsinya dalam perusahaan virtual tersebut.

\section{Kinerja Perusahaan}

Kinerja perusahaan yang diukur dalam penelitian ini adalah kinerja keuangan perusahaan. Kinerja keuangan ini diukur menggunakan laba/rugi bersih perusahaan virtual pada setiap putaran. Informasi laba/rugi bersih ini disediakan oleh sistem informasi di dalam simulasi itu sendiri.

\section{Desain Eksperimen}

Eksperimen dalam penelitian ini menggunakan desain grup kontrol dengan purnauji (post test). Randomisasi digunakan untuk membagi partisipan menjadi dua kelompok. Pengukuran dilakukan hanya satu kali setelah manipulasi dilakukan (Nahartyo, 2013). Eksperimen dilakukan dengan langkah-langkah sebagai berikut:

1. Pemilihan partisipan yaitu mahasiswa akuntansi yang mengikuti mata kuliah Sistem Informasi Manajemen

2. Partisipan memasuki ruang laboratorium komputer dan dipersilahkan memilih tempat duduk yang mereka sukai.

3. Berdasarkan tempat duduknya, partisipan dibagi menjadi beberapa kelompok kecil beranggotakan empat sampai lima orang.

4. Penjelasan tentang penelitian dengan bantuan MonsoonSIM ERP, peserta akan menjalankan perusahaan virtual. Proses bisnis yang harus dikelola meliputi penjualan, pembelian, produksi, manajemen sumber daya manusia dan jasa. 
5. Penentuan kelompok-kelompok mana saja yang akan tergabung menjadi grup pertama, yaitu grup yang diberikan waktu diskusi 1,5 menit. Dengan demikian peneliti sekaligus menentukan kelompokkelompok mana saja yang akan tergabung menjadi grup kedua, yaitu kelompok yang diberi waktu diskusi sepuluh menit. Penentuan ini dilakukan tanpa adanya kriteria khusus, hanya berdasarkan lokasi tempat duduk setiap kelompok. Cara ini dilakukan untuk menjamin adanya randomisasi dalam eskperimen ini.

6. Partisipan menjalankan bisnis virtualnya selama 120 hari virtual. 1 hari virtual sama dengan 40 detik.

7. Setelah selesai, partisipan diminta mengisi kuesioner uji manipulasi dan kuesioner penelitian.

Uji manipulasi dalam penelitian ini dilakukan dengan cara meminta partisipan untuk menjawab tiga pertanyaan seperti yang tampak pada Tabel 1.

\section{Pengujian Hipotesis}

Partisipan yang tidak lolos uji manipulasi serta kuesioner yang tidak valid, dikeluarkan dari data penelitian. Sebelum pengujian hipotesis dilakukan, maka terlebih dahulu dilaksanakan uji validitas untuk variabel kompetensi individu. Pengujian hipotesis dalam penelitian ini menggunakan Structural Equation Modelling (SEM). Pengujian regresi dilakukan menggunakan software AMOS, alat ini dipilih karena hipotesis yang akan diuji adalah hipotesis kausal dengan variabel independen dan dependen yang kompleks (Ghozali, 2017).

\section{Tabel 1. Pertanyaan Uji Manipulasi}

\begin{tabular}{|c|c|c|c|c|c|c|}
\hline NO & KETERANGAN & STS & TS & $\mathrm{N}$ & $\mathrm{S}$ & SS \\
\hline 1. & $\begin{array}{l}\text { Saya merasa waktu yang diberikan cukup } \\
\text { untuk mendiskusikan apa yang diperintahkan }\end{array}$ & & & & & \\
\hline 2. & $\begin{array}{l}\text { Saya merasa waktu yang diberikap cukup } \\
\text { untuk menemukan ide baru untuk } \\
\text { menyelesaikan ERP }\end{array}$ & & & & & \\
\hline 3. & $\begin{array}{l}\text { Saya merasa waktu yang diberikan membuat } \\
\text { saya harus berdiskusi terus-menerus }\end{array}$ & & & & & \\
\hline
\end{tabular}

$\overline{\text { Skala STS=Sangat Tidak Setuju ; TS=Tidak Setuju ; N=Netral ; S=Setuju ; SS=Sangat }}$ Setuju 


\section{Hasil dan Pembahasan}

Uji manipulasi dilakukan dengan meminta partisipan menjawab tiga pertanyaan seperti yang tampak di Tabel 1. Grup kedua yang diberi treatment waktu diskusi 10 menit seharusnya akan memiliki kisaran jawaban antara setuju dan sangat setuju. Sebaliknya grup pertama dengan waktu diskusi 1,5 menit akan memberikan kisaran jawaban dari sangat tidak setuju sampai tidak setuju. Dengan demikian partisipan dinyatakan lolos uji manipulasi. Dari 170 orang partisipan yang lolos uji manipulasi dan mengisi kuesioner yang valid, maka didapatkan gambaran umum partisipan sebagai berikut:

\section{Tabel 2. Statistik Deskriptif}

\begin{tabular}{|c|c|c|c|}
\hline Keterangan & & \multicolumn{2}{|c|}{ Jumlah } \\
\hline Jenis kelamin & $\begin{array}{c}\text { Pria } \\
\text { Wanita }\end{array}$ & \multicolumn{2}{|c|}{$\begin{array}{c}57 \\
113\end{array}$} \\
\hline Jumlah & & \multicolumn{2}{|c|}{170} \\
\hline & 19 & \multicolumn{2}{|c|}{56} \\
\hline & 20 & \multicolumn{2}{|c|}{93} \\
\hline & 21 & \multicolumn{2}{|c|}{13} \\
\hline Usia & 22 & \multicolumn{2}{|c|}{6} \\
\hline & 31 & \multicolumn{2}{|c|}{1} \\
\hline & 35 & \multicolumn{2}{|c|}{1} \\
\hline Jumlah & & \multicolumn{2}{|c|}{170} \\
\hline \multicolumn{4}{|c|}{$\begin{array}{l}\text { Uji validitas dilakukan menggunakan analisis faktor. Intrumen } \\
\text { dikategorikan valid jika memiliki nilai Kaise-Mayer-Olkin (KMO) dan } \\
\text { Bartlett's test yang signifikan. Jika kedua asumsi tersebut telah terpenuhi } \\
\text { maka kemudian kita dapat melihat hasil pengelompokannya pada } \\
\text { Rotated Component Matrix untuk mengevaluasi nilai-nilai intrumen } \\
>0,40 \text {. Hasil pengujian menunjukkan kuesioner yang digunakan dalam } \\
\text { penelitian ini valid dan dapat dilanjutkan dengan pengujian regresi. Hasil } \\
\text { pengujian regresi menggunakan AMOS tampak dalam Tabel } 3 \text {. }\end{array}$} \\
\hline \multicolumn{4}{|l|}{ Tabel 3. Hasil Pengujian Regresi } \\
\hline Relasi & $\begin{array}{l}\text { Standardized } \\
\text { Coefficient }\end{array}$ & $\begin{array}{l}\text { Standard } \\
\text { Error }\end{array}$ & $\mathrm{p}$-value \\
\hline $\begin{array}{l}\text { Kompetensi Individu } \rightarrow \text { Penggunaan } \\
\text { Informasi }\end{array}$ & 0,010 & 0,895 & 0,825 \\
\hline $\begin{array}{l}\text { Knowledge sharing } \rightarrow \text { Penggunaan } \\
\text { Informasi }\end{array}$ & $-0,080$ & 1,177 & 0,075 \\
\hline
\end{tabular}




\begin{tabular}{lccc}
\hline \multicolumn{1}{c}{ Relasi } & $\begin{array}{c}\text { Standardized } \\
\text { Coefficient }\end{array}$ & $\begin{array}{c}\text { Standard } \\
\text { Error }\end{array}$ & p-value \\
\hline $\begin{array}{l}\text { Penggunaan Informasi } \rightarrow \text { Kinerja } \\
\text { Perusahaan }\end{array}$ & 0,130 & 26746,198 & 0,006 \\
\hline
\end{tabular}

Hasil pengujian pengaruh variabel kompetensi individu terhadap penggunaan informasi menunjukkan pengaruh sebesar 0,01 dengan nilai $p$-value menunjukkan nilai 0,825 . Nilai $p$-value yang lebih besar dari $\alpha$ menunjukkan bahwa variabel kompetensi individu tidak memiliki pengaruh signifikan terhadap penggunaan informasi. Hasil uji pengaruh variabel knowledge sharing terhadap penggunaan informasi menghasilkan koefisien regresi sebesar -0,08 dengan $p$-value sebesar 0,075 . Ini menunjukkan variabel knowledge sharing berpengaruh negatif dan signifikan dengan tingkat $\alpha$ sebesar 0,1 . Pengujian pengaruh variabel penggunaan informasi terhadap kinerja perusahaan menghasilkan koefisien regresi sebesar 0,13 dengan p-value sebesar 0,006 . Hal ini menunjukkan bahwa variabel penggunaan informasi berpengaruh positif dan signifikan terhadap kinerja perusahaan pada tingkat $\alpha$ sebesar 0,1 . Secara ringkas hasil pengujian tersebut seperti yang terlihat pada Gambar 2.

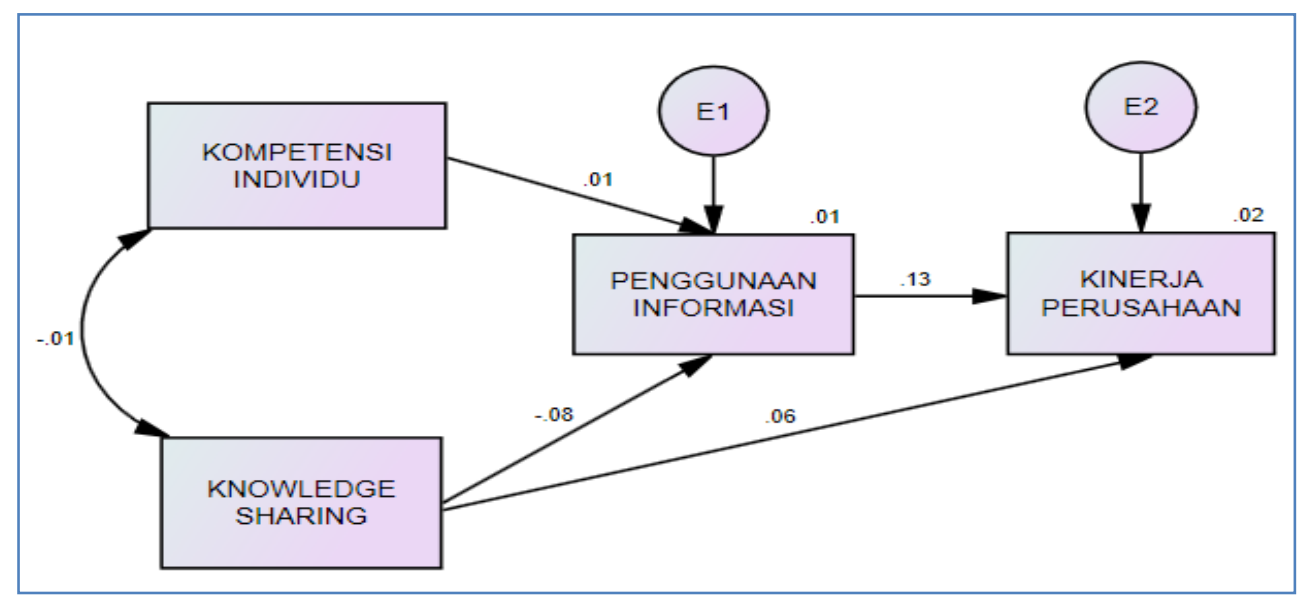

Gambar 2. Hasil Pengujian Regresi (Standardized Coefficient)

Pengujian selanjutnya adalah menguji hubungan tidak langsung antara variabel knowledge sharing terhadap kinerja perusahaan dengan variabel penggunaan informasi sebagai variabel moderasi. Pengujian ini dilakukan dengan Sobel Test dengan hasil pengujian seperti tampak dalam Tabel 4. 
Tabel 4. Hasil Pengujian Sobel Test

\begin{tabular}{ll}
\hline & Sobel Test \\
\hline Test statistic & $-1,4897$ \\
Std Error & 102381,8722 \\
p-value & 0,1363 \\
\hline
\end{tabular}

Hasil sobel test menunjukkan $p$-value sebesar 0,14 yang berarti tidak ada pengaruh tidak langsung yang signifikan antara variabel knowledge sharing dengan kinerja perusahaan.

Hasil penelitian ini menunjukkan kompetensi individu tidak berpengaruh terhadap penggunaan informasi. Kompetensi individu dalam penelitian ini didefinisikan sebagai kompetensi teknis seorang individu dalam menggunakan hardware dan software yang terkait. Greene, Yu, dan Copeland, (2014) dalam penelitiannya berpendapat bahwa kapabilitas teknologi informasi bukan hanya sekedar kemampuan teknis. Mereka menyatakan bahwa literasi digital lebih dari sekedar kemampuan untuk menggunakan atau mengoperasikan teknologi informasi.

Literasi digital terdiri dari dua aspek kritis. Aspek yang pertama adalah kemampuan untuk mencari lalu mengatur informasi yang didapatkan. Aspek yang kedua adalah kemampuan untuk memeriksa dan mengintegrasikan sumber-sumber informasi tersebut. Penelitian selanjutnya dari Greene, Copeland, Deekens, dan Yu, (2017) menunjukkan bahwa individu dengan literasi digital yang lebih tinggi akan cenderung lebih baik dalam proses pencarian dan pemahaman pengetahuan baru. Individu dengan literasi digital yang lebih tinggi cenderung memiliki kemampuan belajar mandiri yang lebih baik. Kemampuan belajar mandiri ini sering disebut dengan self-regulated learning (SRL). Kemampuan belajar mandiri (SRL) mampu berikan pengetahuan dan informasi baru bagi individu tersebut.

Kapabilitas teknologi informasi seorang individu akan mempengaruhi adopsi teknologi informasi oleh individu tersebut (Nguyen, 2009). Bila dihadapkan pada teknologi yang dianggap mudah secara teknis, maka kemampuan pengoperasian komputer tidak menjadi kemampuan yang berpengaruh signifikan pada penggunaan informasi. Individu lebih banyak membutuhkan kemampuan untuk mencari dan menganalisa sebuah sumber informasi. Setelah melakukan analisa, barulah individu 
tersebut baru dapat memutuskan, memilih dan memanfaatkan informasi secara optimal. Kompetensi individu dalam menganalisa akan membuat individu mampu memilah informasi yang bermanfaat dan yang tidak. Kompetensi individu dalam memberikan sumber informasi juga akan menentukan informasi-informasi yang akan digunakan dalam proses bisnis.

Kapabilitas teknis pengoperasian teknologi informasi bisa tidak berpengaruh pada derajat penggunaan informasi saat individu tersebut berhadapan dengan teknologi yang dianggap mudah untuk dioperasikan. Individu tersebut tidak lagi menganggap kemampuan teknis pengoperasian sistem informasi sebagai faktor pendukung tapi juga bukan sebagai faktor penghambat penggunaan informasi. Faktor literasi digital dalam arti kemampuan analisa menjadi lebih dibutuhkan dalam penggunaan informasi (Greene et al., 2017, 2014).

Kang et al., (2012) dalam Darban, Kwak, Deng, Srite, dan Lee (2016) menyatakan bahwa di dalam sebuah tim, seorang individu mengandalkan informasi dari rekan satu timnya untuk memahami sebuah informasi. Hal ini menunjukkan bahwa seorang individu masih tetap dapat menggunakan informasi tanpa kemampuan teknis yang tinggi karena didukung oleh rekan satu tim di dalam organisasi tersebut. Hasil penelitian sebelumnya menunjukkan bahwa faktor-faktor lingkungan sangat mempengaruhi penggunaan informasi (Rahmawati, 2012). Teori TOE juga menyatakan bahwa faktor lingkungan turut mempengaruhi kinerja individu (Oliveira et al., 2011). Dukungan faktor lingkungan dan informasi dari rekan satu tim dapat menutupi kekurangan kompetensi teknis individu.

Hasil pengujian selanjutnya menunjukkan knowledge sharing memang memiliki pengaruh terhadap penggunaan informasi. Berbeda dengan penelitian-penelitian sebelumnya, hasil pengujian dalam penelitian ini menunjukkan, meskipun pengaruhnya signifikan, tapi knowledge sharing memiliki arah pengaruh negatif. Ini menunjukkan bahwa bagi partisipan dalam penelitian ini, semakin banyak informasi yang mereka dapatkan di dalam tim, justru mereka akan menggunakan lebih sedikit jenis informasi.

Hal ini menunjukkan bahwa dalam eksperimen ini partisipan akan cenderung lebih banyak mencari dan menggunakan informasi secara 
mandiri saat tidak dapat mengandalkan sharing informasi dari rekan satu timnya. Temuan ini menunjukkan bahwa di dalam organisasi yang memiliki keselarasan tujuan (goal congruence), masing-masing individu di dalam tim akan berusaha untuk mencapai tujuan yang sama secara mandiri (Romney \& Steinbart, 2015). Meskipun kondisi tidak memungkinkan untuk terjadinya knowledge sharing secara optimal, masing-masing anggota tim akan tetap menjalankan fungsinya untuk mencapai tujuan. Dalam penelitian ini, tujuan dari setiap tim adalah menjalankan perusahaan virtual dan mengelola keuangan perusahaan virtual tersebut sehingga terhindar dari pailit. Kesamaan tujuan ini menyebabkan setiap anggota tim berusaha menjalankan fungsinya dengan baik sehingga operasional perusahaan dapat tetap berjalan serta tujuan utama dari perusahaan tersebut tercapai.

Selain kondisi keselarasan tujuan (goal congruence), beberapa penelitian membuktikan bahwa diperlukan lebih dari sekedar knowledge sharing untuk dapat menaikkan kinerja perusahaan. Penelitian Peng, Quan, Zhang, dan Dubinsky (2016) menyatakan bahwa faktor yang memediasi pengaruh teknologi informasi terhadap kinerja adalah kemampuan untuk memanajemen kapabilitas setiap fungsi di dalam proses bisnis internal dan eksternal. Hal ini senada dengan yang ditemukan oleh Mithas, Ramasubbu, dan Sambamurthy (2011) dalam penelitiannya tentang manajemen pengetahuan. Penelitian mereka membuktikan bahwa faktor yang berperan besar dalam peningkatan kinerja perusahaan adalah kapabilitas untuk mengatur dan mendistribusikan pengetahuan di dalam organisasi. Kesempatan dan fasilitas untuk memungkinkan terjadinya knowledge sharing hanyalah salah satu faktor yang mendukung manajemen pengetahuan internal yang baik. Pengungkit kinerja yang sesungguhnya adalah seberapa baik pengetahuan didistribusikan secara internal untuk kemudian dimanfaatkan oleh masing-masing fungsi.

Penelitian ini tidak dapat membuktikan bahwa knowledge sharing memiliki pengaruh tidak langsung yang signifikan terhadap kinerja perusahaan. Hal ini menegaskan kondisi lingkungan perusahaan secara internal memiliki pengaruh terhadap kinerja perusahaan. Kesempatan atau kemungkinan terjadinya knowledge sharing hanyalah salah satu di antara sekian banyak faktor lingkungan tersebut. Temuan ini juga 
menunjukkan masih banyak faktor-faktor lain yang mempengaruhi penggunaan informasi dalam pengambilan keputusan.

Penelitian ini juga menemukan bahwa penggunaan informasi berpengaruh positif terhadap kinerja perusahaan. Sesuai dengan peran teknologi dan sistem informasi sebagai infrastruktur pendukung (Romney \& Steinbart, 2015), maka penggunaan informasi menjadi dasar pengambilan keputusan yang tepat dalam operasional perusahaan. Temuan ini juga menunjukkan bahwa informasi di dalam organisasi harus dikembangkan menjadi pengetahuan. Turban, Volonino, dan Woods (2015) mendefinisikan pengetahuan dalam organisasi sebagai informasi yang sudah diproses, diorganisasi dan disajikan dalam konteks yang bermakna untuk menunjukkan pemahaman, pengalaman, akumulasi pembelajaran dan keahlian karena pengetahuan tersebut dapat diterapkan pada masalah atau aktivitas yang spesifik. Teknologi informasi di masa depan mengarahkan pengembangannya untuk menyediakan decision support system (DSS) dan analisa data, bukan hanya sekedar query maupun laporan semata.

Selain hasil-hasil pengujian di atas, penelitian ini tetap memberikan bukti bahwa penggunaan informasi memang berpengaruh positif terhadap kinerja perusahaan. Informasi yang didapatkan dari sebuah sistem informasi terkomputerisasi, yang diperbarui setiap saat, sangat bermanfaat dalam pengambilan keputusan perusahaan. Kapabilitas manajemen teknologi informasi yang ditunjang dengan fleksibilitas infrastruktur teknologi informasi itu sendiri akan mendukung kapabilitas proses bisnis yang dinamis (Kim, Shin, Kim, \& Lee, 2011). Proses bisnis yang dinamis inilah yang dapat meningkatkan kecepatan proses pengambilan keputusan. Proses pengambilan keputusan yang dinamis ini pada akhirnya membawa perusahaan untuk memperoleh kinerja keuangan yang lebih baik. Oleh karena itu, Ordanini dan Rubera (2010) menyatakan bahwa untuk meningkatkan kinerja perusahaan, perusahaan harus memiliki perangkat kapabilitas teknologi informasi yang lengkap. Kapabilitas teknologi informasi yang harus dimiliki perusahaan secara internal meliputi keahlian dalam bidang teknologi informasi, pelatihan, dan reorganisasi proses bisnis untuk menyelaraskan sistem informasi dan proses bisnis di tiap-tiap departemen. Penyelarasan ini penting karena tingkat kepercayaan pengguna terhadap teknologi dan sistem informasi tersebut 
berpengaruh pada kesuksesan operasional perusahaan (Garrison, Wakefield, \& Kim, 2015).

\section{Simpulan}

Teknologi bisa hadir dalam perusahaan dalam banyak aspek. Salah satu bentuk pemanfaatan teknologi adalah sistem informasi dalam sebuah perusahaan. Hasil penelitian ini menunjukkan bahwa yang mendukung peningkatan kinerja keuangan perusahaan lebih dari sekedar keberadaan sistem informasi tersebut, melainkan tingkat penggunaan informasi yang dihasilkan sistem tersebut. Informasi sebagai luaran sistem baru dapat memberikan kontribusi saat informasi tersebut digunakan dalam proses pengambilan keputusan. Dengan demikian, penting bagi perusahaan untuk memastikan informasi yang dihasilkan oleh sistem tersebut dimanfaatkan secara optimal dalam pengambilan keputusan.

Untuk dapat memanfaatkan informasi secara optimal diperlukan kompetensi individu yang memadai. Kompetensi individu, dalam kaitannya dengan penggunaan informasi, dapat terdiri dari berbagai macam kapabilitas. Literasi digital tidak lagi berupa kemampuan teknis pengoperasian komputer saja. Literasi digital mencakup kemampuan mencari dan menganalisa suatu informasi. Perkembangan teknologi membuat sistem informasi menjadi semakin ramah pengguna (user friendly). Artinya, para pengguna tidak mengalami kendala teknis yang berarti dalam mengakses ataupun mengolah informasi.

Kompetensi individu tidak lagi dapat dilihat dari kemampuan teknis semata. Kompetensi individu harus diukur dari kemampuan menganalisa informasi yang dihasilkan oleh sistem. Dengan meningkatnya kemampuan individu dalam menganalisa informasi, knowledge sharing dapat membuat seorang individu memiliki terlalu banyak informasi. Pada akhirnya individu tersebut akan memilah kembali informasi mana yang akan ia gunakan. Individu cenderung akan mempercayai informasi yang dianalisanya sendiri dibandingkan informasi yang didapat dari rekan-rekannya.

Pesatnya perkembangan teknologi sistem informasi meningkatkan kuantitas informasi yang dihasilkan. Tingkat penggunaan informasi dapat dilihat dari seberapa banyak informasi yang dimanfaatkan dalam 
proses pengambilan keputusan. Akan lebih baik lagi jika tingkat penggunaan informasi dapat diukur dari tingkat signifikansi informasi tersebut dalam proses pengambilan keputusan. Pengukuran variabel kompetensi individu dan knowledge sharing juga harus dikembangkan menjadi ukuran-ukuran yang lebih kualitatif.

Penelitian ini bagaimanapun juga memiliki beberapa keterbatasan yang dapat diperbaiki pada penelitian selanjutnya. Kompetensi individu dalam penelitian ini didefinisikan sebagai kemampuan teknis pengoperasian komputer. Variabel ini dapat dikembangkan dengan cara mendiversifikasi pengukuran terhadap variabel kompetensi individu. Kompetensi individu dapat diukur dengan tingkat literasi digital. Literasi digital yang dimaksud adalah kemampuan untuk mencari, mengatur dan juga memeriksa sumber-sumber informasi. Lebih jauh lagi, literasi digital dapat diartikan sebagai kemampuan untuk memahami informasi yang diperoleh secara mandiri dari sebuah sistem informasi.

Variabel knowledge sharing dalam penelitian ini diukur dengan durasi waktu berdiskusi. Ukuran ini tidak dapat mengukur seberapa efektif dan efisien proses pembagian pengetahuan antara individu dalam organisasi. Untuk itu pada penelitian selanjutnya, ukuran variabel knowledge sharing dapat dikembangkan menjadi instrumen yang mengukur efektivitas dan efisiensi proses pembagian pengetahuan di dalam sebuah organisasi. Kapabilitas untuk menyerap informasi yang dibagikan dalam organisasi juga dapat dipertimbangkan sebagai ukuran dari variabel knowledge sharing. Hal ini disebabkan karena knowledge sharing hanya merupakan salah satu faktor dari knowledge management. Untuk dapat memediasi peningkatan kinerja perusahaan, maka knowledge sharing bukan hanya berarti berbagi atau membagikan informasi, tetapi termasuk proses penyerapan informasi dan bagaimana informasi tersebut diaplikasikan dalam proses pekerjaan sehari-hari.

Variabel kinerja perusahaan yang dalam penelitian ini hanya dilihat berdasarkan laba atau rugi, tanpa mempertimbangkan faktor keberlanjutan (sustainability) ataupun ukuran kinerja keuangan yang lainnya. Faktor keberlanjutan menjadi indikator kinerja yang layak dipertimbangkan karena salah satu tujuan dari perusahaan tentunya adalah operasional yang berkelanjutan. Ukuran kinerja keuangan yang lainnya juga dapat mengukur faktor keberlanjutan dan kondisi keuangan 
perusahaan dengan lebih tepat. Untuk penelitian yang akan datang, variabel kinerja dapat diperluas dimensi pengukurannya.

Demikian juga halnya dengan dua variabel independen dalam penelitian ini. Penelitian selanjutnya dengan instrumen pengukuran yang berbeda untuk variabel kompetensi individu dan knowledge sharing dapat memberikan penjelasan yang lebih baik mengenai bagaimana kedua faktor tersebut menjadi faktor pengungkit (leverage) kinerja keuangan perusahaan. Pemahaman bahwa penggunaan informasi berpengaruh positif dan signifikan terhadap kinerja keuangan perusahaan harus didukung dengan pengetahuan mengenai faktor-faktor yang mempengaruhi penggunaan informasi itu sendiri. Dengan demikian, perusahaan ataupun organisasi bisa memahami kapabilitas teknologi informasi apa saja yang harus dimiliki secara internal. Kapabilitas teknologi informasi memiliki aspek yang beraneka ragam, mulai dari kemampuan teknis individu, infrastruktur teknologi informasi, maupun knowledge management. Luasnya cakupan faktor kapabilitas teknologi informasi ini menyebabkan perusahaan perlu mengetahui dengan pasti aspek apa yang perlu ditingkatkan untuk dapat memanfaatkan sistem informasi secara maksimal.

\section{Daftar Pustaka}

Alzoubi, A. (2011). The Effectiveness of the Accounting Information System Under the Enterprise Resources Planning (ERP) A Study on Al Hassan Qualified Industrial Zone's (QIZ) Companies. Research Journal of Finance and Accounting, 2(11), 2222-2847.

Brynjolfsson, E., Hitt, L. ., \& Kim, H. . (2011). Strength in Numbers : How Does Data-Driven Decisionmaking Affect Firm Performance?

Brynjolfsson, E., \& Mcelheran, K. (2016). The Rapid Adoption of Data-Driven DecisionMaking. American Economic Review, 106(5), 133-139.

Caya, O., Léger, P. M., Grebot, T., \& Brunelle, E. (2014). Integrating, sharing, and sourcing knowledge in an ERP usage context. Knowledge Management Research and Practice, 12(2), 193-202. https://doi.org/10.1057/kmrp.2012.54

Chae, B. (Kevin), Yang, C., Olson, D., \& Sheu, C. (2014). The impact of advanced analytics and data accuracy on operational performance : A contingent resource based theory (RBT) perspective. Decision Support Systems, 59, 119-126. https://doi.org/10.1016/j.dss.2013.10.012

Choi, S. Y., Lee, H., \& Yoo, Y. (2010). The Impact of Information Technology and Transactive Memory Systems on Knowledge Sharing , Application , and Team Performance : A Field Study. MIS Quarterly, 34(4), 855-870. 
Citroen, C. L. (2011). The Role of Information in Strategic Decision-making. International Journal of Information Management, 31(6), 493-501. https://doi.org/10.1016/j.ijinfomgt.2011.02.005

Darban, M., Kwak, D.-H. (Austin), Deng, S. (Lance), Srite, M., \& Lee, S. (2016). Antecedents and consequences of perceived knowledge update in the context of an ERP simulation game: A multi-level perspective. Computers \& Education, 103, 87-98. https://doi.org/10.1016/J.COMPEDU.2016.09.011

DeLone, W. H., \& McLean, E. R. (2003). The DeLone and McLean model of information systems success: A ten-year update. Journal of Management Information Systems, 19(4), 9-30. https://doi.org/10.1080/07421222.2003.11045748

Turban, E., Linda Volonino, G. R. W. (2015). Information Technology for Management (10th ed in). John Wiley \& sons (Asia) Ptd. Ltd.

Emeka-Nwokeji, N. (2012). Repositioning Accounting Information System Through Effective Data Quality Management: A Framework For Reducing Costs And Improving Performance. International Journal of Scientific \& Technology ..., 1(10), 86-94.

Frestilia, N. (2013). Pengaruh Pemanfaatan Teknologi Informasi, Karakteristik Informasi Sistem Akuntansi Manajemen dan Ketidakpastian Lingkungan Terhadap Kinerja Manajerial. Jurnal Akuntansi, 1(1).

Garrison, G., Wakefield, R. L., \& Kim, S. (2015). The effects of IT capabilities and delivery model on cloud computing success and firm performance for cloud supported processes and operations. International Journal of Information Management, 35(4), 377-393. https://doi.org/10.1016/j.ijinfomgt.2015.03.001

Ghobakhloo, M., Arias-aranda, D., \& Benitez-amado, J. (2011). Adoption of e-commerce applications in SMEs. Industrial Management \& Data Systems, 111(8), 12381269. https://doi.org/10.1108/02635571111170785

Ghozali, I. (2017). Structural Equation Modeling Konsep dan Aplikasi dengan Program Amos 24. Semarang: Badan Penerbit Universitas Diponegoro.

Greene, J. A., Copeland, D. Z., Deekens, V. M., \& Yu, S. (2017). Beyond Knowledge:Examining Digital Literacy's Role in the Acquisition of Understanding in Science. Computers \& Education. https://doi.org/10.1016/j.compedu.2017.10.003

Greene, J. A., Yu, S. B., \& Copeland, D. Z. (2014). Measuring Critical Components of Digital Literacy and their Relationships with Learning. Computers \& Education. https://doi.org/10.1016/j.compedu.2014.03.008

Handayani, R. (2005). ANALISIS FAKTOR-FAKTOR YANG MEMPENGARUHI MINATPEMANFAATAN SISTEM INFORMASI DANPENGGUNAAN SISTEM INFORMASI(Studi Empiris Pada Perusahaan Manufaktur di Bursa Efek Jakarta).

Kang, S., Lim, K. H., Kim, M. S., \& Yang, H. D. (2012). A multilevel analysis of the effect of group appropriation on collaborative technologies use and performance. Information Systems Research, 23(1), 214-230. https://doi.org/10.1287/isre.1100.0342 
Kharuddin, S., Ashhari, Z. M., \& Nassir, A. M. (2010). Information System and Firms ' Performance : The Case of Malaysian Small Medium Enterprises. International Business Research, 3(4), 28-35.

Kim, G., Shin, B., Kim, K. K., \& Lee, H. G. (2011). IT Capabilities , Process-Oriented Dynamic Capabilities, and Firm Financial Performance. Journal of The Association for Information Systems, 12(7), 487-517.

Liang, T., You, J.-J., \& Liu, C. (2010). A resource-based perspective on information technology and firm performance : a meta analysis. Industrial Management \& Data Systems, $110(8), \quad 1138-1158$. https://doi.org/10.1108/02635571011077807

Liu, H., Ke, W., Kee, K., \& Hua, Z. (2013). The impact of IT capabilities on fi rm performance: The mediating roles of absorptive capacity and supply chain agility. Decision Support Systems, 54(3), 1452-1462. https://doi.org/10.1016/j.dss.2012.12.016

Maruping, L. M., \& Magni, M. (2012). What's the Weather Like? The Effect of Team Learning Climate, Empowerment Climate, and Gender on Individuals' Technology Exploration and Use. Journal of Management Information Systems, 29(1), 79-114. https://doi.org/10.2753/MIS0742-1222290103

Mills, A. M. (2011). Knowledge management and organizational performance: a decomposed view. Journal of Knowledge Management, 15(1), 156-171.

Mithas, S., Ramasubbu, N., \& Sambamurthy, V. (2011). How Information Management Capability Influences Firm Performance1. MIS Quarterly, 35(1), 237-256.

Mithas, S., Tafti, A., Bardhan, I., \& Goh, J. M. (2012). Information Technology and Firm Profitability: Mechanisms and Empirical Evidence. MIS Quarterly, 36(1), 205224.

Nahartyo, E. (2013). Desain dan Implementasi Riset Eksperimen (2nd ed.). Yogyakarta: UPP STIM YKPN.

Nguyen, T. (2009). Information technology adoption in SMEs: an integrated framework. International Journal of Entrepreneurial Behavior \& Research, 15(2), 162-186. https://doi.org/10.1108/13552550910944566

Oliveira, T., Martins, M. F., \& Lisboa, U. N. De. (2011). Literature Review of Information Technology Adoption Models at Firm Level. The Electronic Journal Information Systems Evaluation, 14(1), 110-121.

Ordanini, A., \& Rubera, G. (2010). How does the application of an IT service innovation affect firm performance? A theoretical framework and empirical analysis on ecommerce. Information \& Management, 47, 60-67. https://doi.org/10.1016/j.im.2009.10.003

Peng, J., Quan, J., Zhang, G., \& Dubinsky, A. J. (2016). International Journal of I Mediation effect of business process and supply chain management capabilities on the impact of IT on firm performance: Evidence from Chinese firms $\leftleftarrows$. International Journal of Information Management, 36(1), 89-96. https://doi.org/10.1016/j.ijinfomgt.2015.09.006

Rahayu, R., \& Day, J. (2015). Determinant Factors of E-commerce Adoption by SMEs in Developing Country : Evidence from Indonesia. Procedia - Social and Behavioral Sciences, 195, 142-150. https://doi.org/10.1016/j.sbspro.2015.06.423 
Rahmawati, D. (2012). Analisis Faktor Faktor yang Berpengaruh Terhadap Pemanfaatan Teknologi Informasi. Jurnal Ekonomi Dan Pendidikan, 5(1). https://doi.org/10.21831/jep.v5i1.606

Romney, M. B., \& Steinbart, P. J. (2015). Accounting Information System (13th ed.). Prentice-Hall.

Saira, K., Zariyawati, M. A., \& Annuar, M. N. (2014). Information System and Firms' Performance: The Case of Malaysian Small Medium Enterprises. International Business Research, 3(4). https://doi.org/10.5539/ibr.v3n4p28

Shah, S., Horne, A., \& Capella, J. (2012, April). Good Data Won't Guarantee Good Decisions. Harvard Business Review.

Siynabola, T. T. (2012). Accounting Information As an Aid To Management Decision Making. International Journal of Management and Social Sciences ResearchXplore International Research Journal Consortium, 1(3), 2319-4421.

Soudani, S. N. (2012). The Usefulness of an Accounting Information System for Effective Organizational Performance. International Journal of Economics and Finance, 4(5), 136-145. https://doi.org/10.5539/ijef.v4n5p136

Vacaro, A., Parente, R., \& Veloso, F. M. (2010). Knowledge Management Tools, InterOrganizational Relationships, Innovation and Firm Performance. Technological Forecasting and Social Changes, 77(7), 1076-1089. https://doi.org/https://doi.org/10.1016/j.techfore.2010.02.006

Wahyudi, M. (2009). Analisis Faktor-faktor yang Mempengaruhi Penggunaan Informasi Akuntansi Pada Usaha Kecil dan Menengah (UKM) di Yogyakarta.

Wang, S., \& Noe, R. A. (2010). Knowledge sharing: A review and directions for future research. Human Resource Management Review, 20(2), 115-131. https://doi.org/10.1016/j.hrmr.2009.10.001

Wang, Z., \& Wang, N. (2012). Knowledge Sharing, Innovation and Firm Performance. Expert System With Applications, 39(10), 8899-8908.

Widiastuti, K. (2011). Manajerial Dengan Karakteristik Sistem Akuntansi Manajemen (SAM) Sebagai Variabel Intervening. Universitas Diponegoro. 